\title{
GUITAR PLAYING ROBOT, A TOOL ASSISTING INSTRUMENTAL RESEARCH
}

\begin{abstract}
This article is about the use of an automatic mechanism able to play an instrument in research about playing repeatability. Repeatability in this case refers to the time intervals between played notes in sequences. The subject will be discussed based on a guitar playing robot. During the research with the use of guitar playing robots, some conclusions were made that confirm that humans are unable to play sound sequences twice while maintaining high repeatability. It has also been proven that the use of a robotic musical instrument (RMI) helps obtain playing repeatability of sound sequences much more accurately than that obtained by a human musician.
\end{abstract}

Keywords: guitar, robotics, repeatability, music, instrument

\section{ROBOT GRAJACY NA GITARZE, NARZĘDZIE WSPOMAGAJĄCE BADANIA NAD INSTRUMENTAMI}

Artykut omawia zastosowanie automatycznego mechanizmu, grajacego na instrumentach, $w$ badaniach dotyczacych powtarzalności gry. W tym wypadku powtarzalność odnosi się do odstępów czasowych pomiędzy odgrywanymi w sekwencji dźwiękami. Podczas przeprowadzonych badań z wykorzystaniem robotów grających na gitarze uzyskano wyniki świadczace o tym, że człowiek nie jest $w$ stanie zagrać dwukrotnie sekwencji dźwięków z zachowaniem wysokiej powtarzalności. Wykazano również, że zastosowanie instrumentu robomuzycznego (RMI) pozwala uzyskać powtarzalność odgrywanej sekwencji o wiele wyższa niż uzyskana przez człowieka.

Stowa kluczowe: gitara, robotyka, powtarzalność, muzyka, instrument

\section{INTRODUCTION}

In 1863, Fourneiux built the Pianola; this device is called a robotic musical instrument (RMI) (Kapur 2005), a mechanical device that can play a musical instrument normally operated by a human player. In the case of the Pianola, it was an upright piano. This was the first of many mechanical musicians. The name of the field of study for such devices is called robotic musical engineering (RME) (Kapur 2005). The design industry of musical instruments is not developing as fast as other industries because of the limited target group (it is not easy to invest a lot of money into research and development of proven solutions). Many years have passed since the first RMI was built, and the creation of such devices does not involve large investments any more. Affordable technology gives us possibilities to build robots that can play an instrument, autonomously or automatically (Kapur 2005). Nowadays, it is possible to implement such robots for the purpose of increasing knowledge about the instruments. A robot created for such a purpose was a guitar playing one (Tokarczyk 2014).

Over the years, many researchers investigated the field of musical instruments. Some of them eliminated the human factor in their research by replacing it with a mechanical player. In the year 2000, the article "Measuring the Quality of Guitar Tone" (Sali and Kopac 2000) was published. The main goal of this research was to determine whether it is possible to perform a quality test on freshly built guitars. For their test, a plucking device was built (Fig. 1) to increase the repeatability of the pluck so the guitar pick would hit in the same place on the string every time.

With the use of a mechanical plucking device, it was possible for the researchers to obtain a system used to recognize if there were any defects in the guitar (Sali and Kopac 2000).

The main purpose of the system presented in this article is to perform quality tests on guitars. The elaborated robot is only a prototype, built in such a way that it can be developed depending on the needs of the research (Tokarczyk 2015). In the future, the robot will be used in research about the vibrating elements of a guitar. The authors are aware of the device limitations when it comes to musical performances. It is possible, though, to implement it for musical performances after some changes, like improving the plucking mechanism by enlarging the range of the pushed frets. It would be also necessary to use software created on the base of the rules of human performance (Rasmussen 1983, Delekta and Pluta 2015). With such software, it would be possible to force a repeatable system to simulate the human way of unrepeatable music performance.

* AGH University of Science and Technology, Faculty of Mechanical Engineering and Robotics, Department of Mechanics and Vibroacoustics, Krakow, Poland; e-mail: danielt@agh.edu.pl 


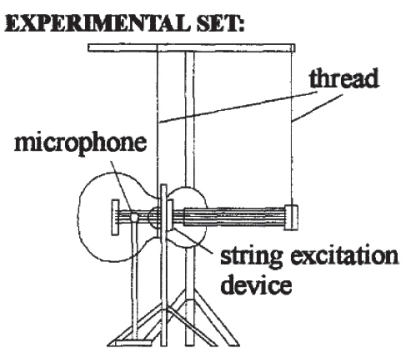

\section{MICROPHONE POSTITON:}

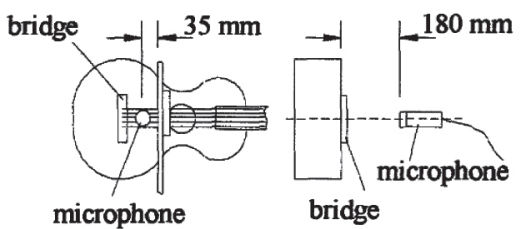

STRING EXCTTATION DEVICE:
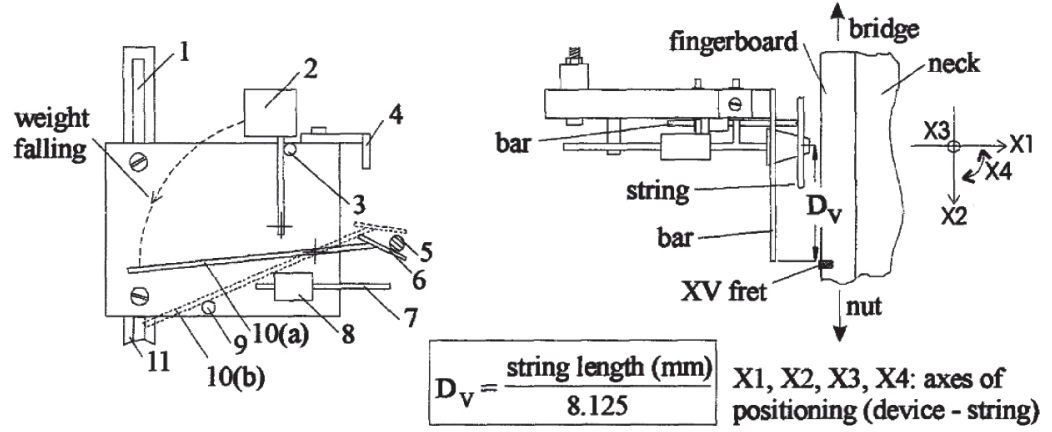

Fig. 1. Device schematics used by Sali and Kopac in their experiment as described in (Sali and Kopac 2000)

\section{GUITAR PLAYING ROBOT}

\subsection{Motivation}

The guitar is a string instrument composed of many elements (Fig. 2). The type of material used to build a guitar, shape of the body, type of the bridge used, and strings are a few of the many elements that can be grouped into the first factor set that influences the sound produced by the guitar. The second factor set refers to the human player and the playing methods: the point, angle, and value of the force input during the plucking of the strings. The main reason for using a guitar-playing robot was to eliminate the influence of the second factor set. The method of plucking is mostly responsible for play dynamics and timbre; research on the repeatability of plucking does not require any advanced techniques of playing. Repeatability in this case refers to the time intervals between the played notes in the sequences. The device was designed and built so it would strike the strings of the instrument in the same places at the same angle and with the same force each time a pluck is performed. The human player also can influence the sound produced by the guitar with a method of pressing and releasing the strings on the freeboard. This factor was taken into consideration during the designing process of the robot. The pushing parts are created so the string will be pressed in the same place just before it is necessary to pluck it. The release is also performed at a proper time, so it will not negatively affect the sound produced from the instrument.
The robot was built in modules that were easily installed on any acoustic guitar. Each module has many calibration elements, so it can fit to different arrangement of strings, types of bridges, and body sizes.

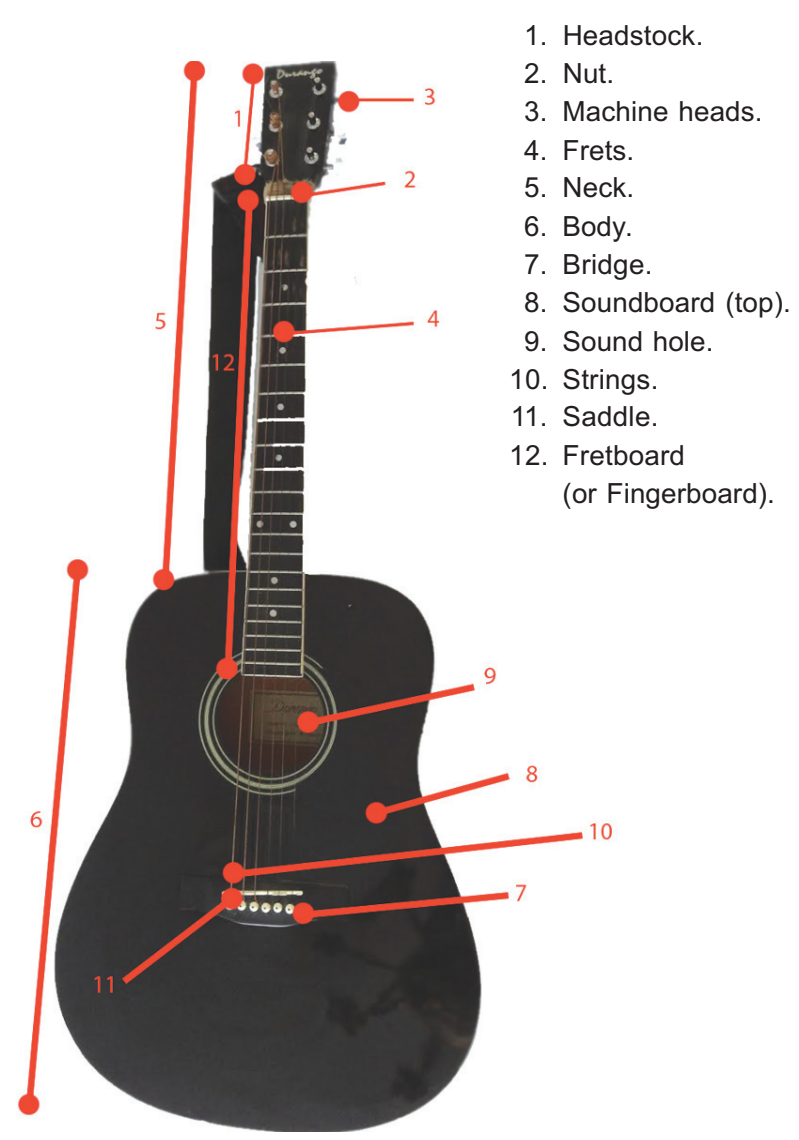

Fig. 2. Acoustic guitar parts schematics 


\subsection{Robot structure description}

The robot built to play the guitar consists of three modules:

- string-plucking module - for right-hand simulation (Fig. 3);

- string-pushing module - for left-hand simulation (Fig. 4);

- control module (Figs. 5-7).
The right-hand simulation module uses six plucking elements from a modified automotive relay, one per string. In accordance with the assumed research purpose, it was not necessary for the current solution to perform various dynamics levels; therefore, the relay generates only two states ( 0 or 1$)$. Both states produce a string pluck.
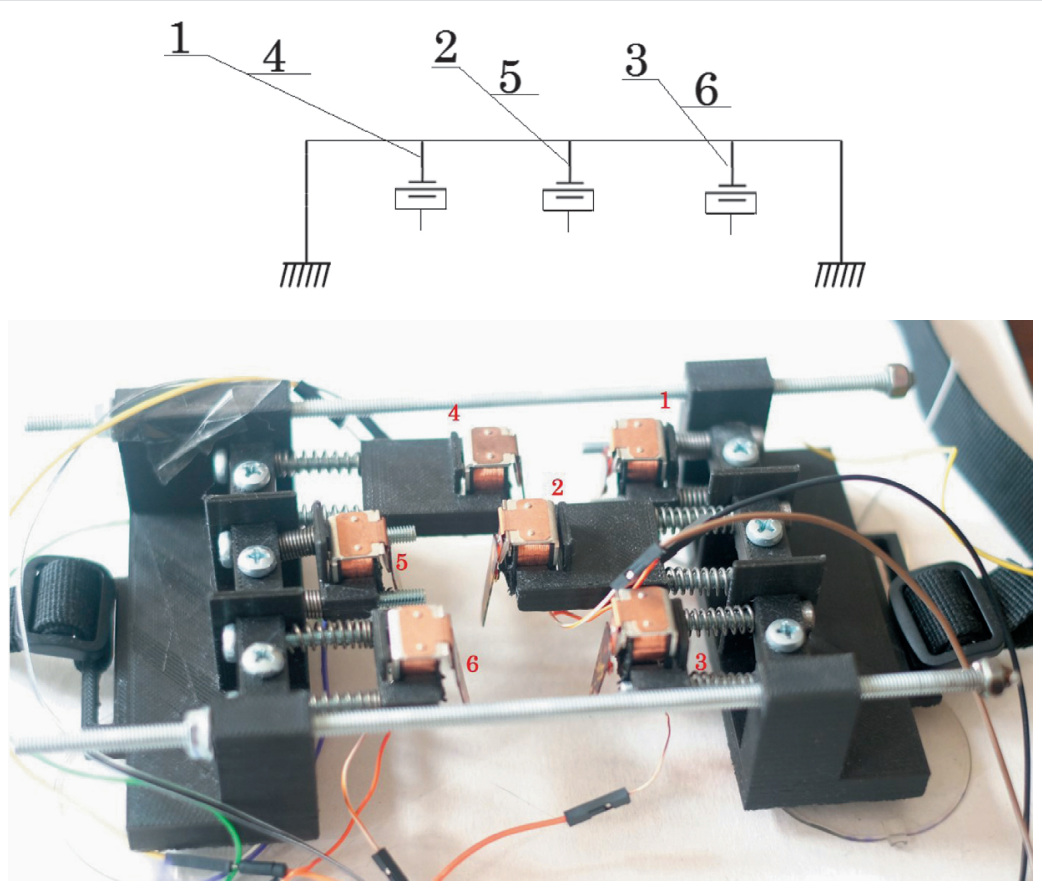

Fig. 3. String-plucking module and its kinematic chain: 1, 2, 3, 4, 5, 6 highlighted in the figure are relays converted into string-plucking mechanisms
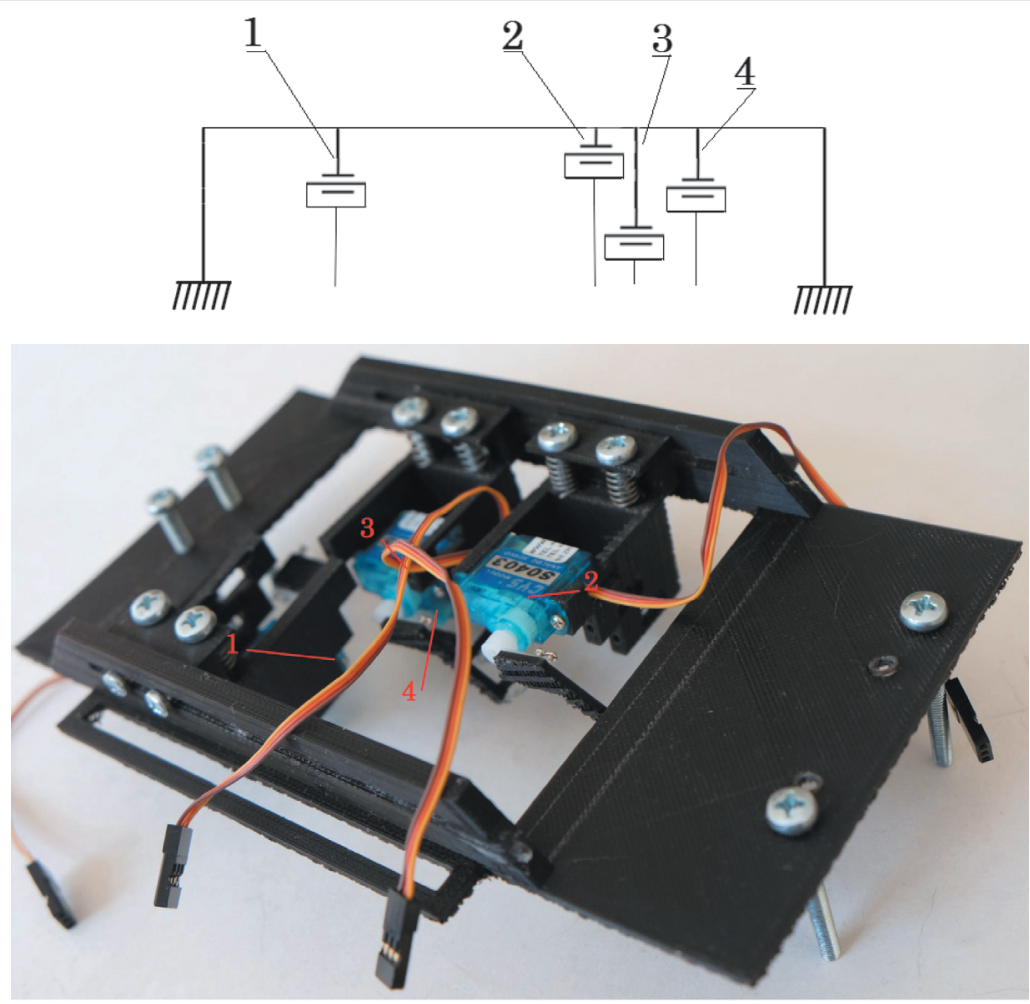

Fig. 4. String-pushing module and its kinematic chain: 1, 2, 3, 4 highlighted in the figure are servos used as string-pressing devices 


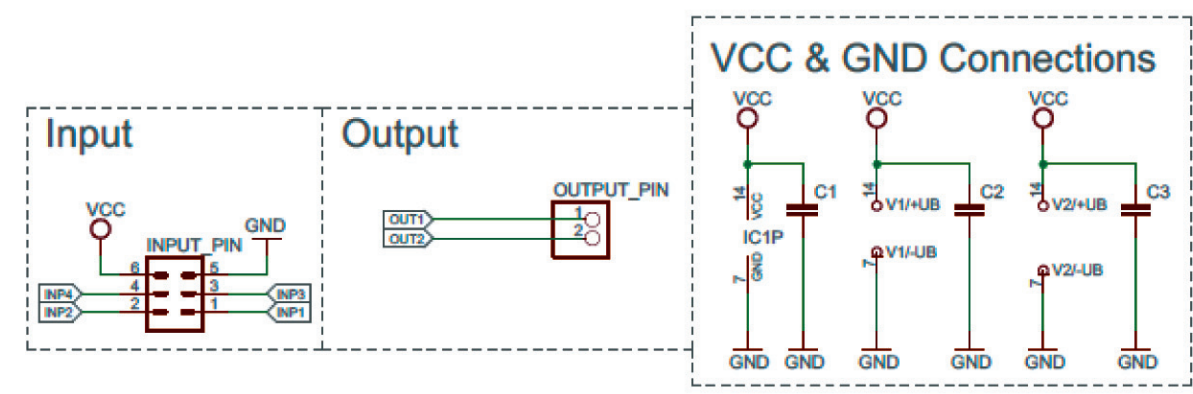

\section{Logic system}

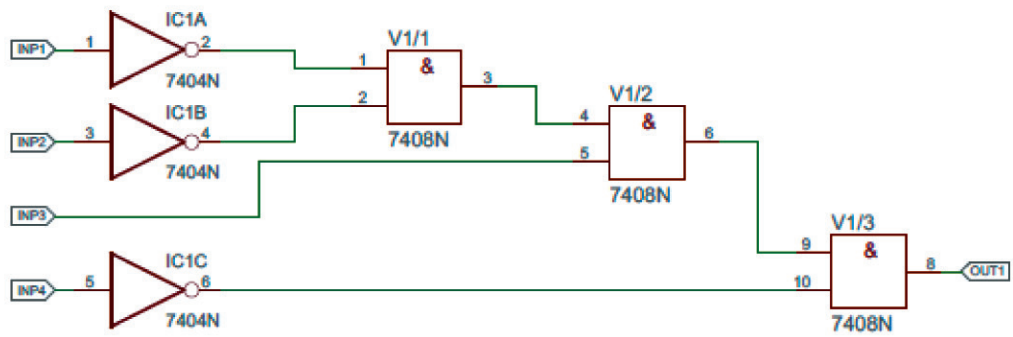

Unused pins grounded
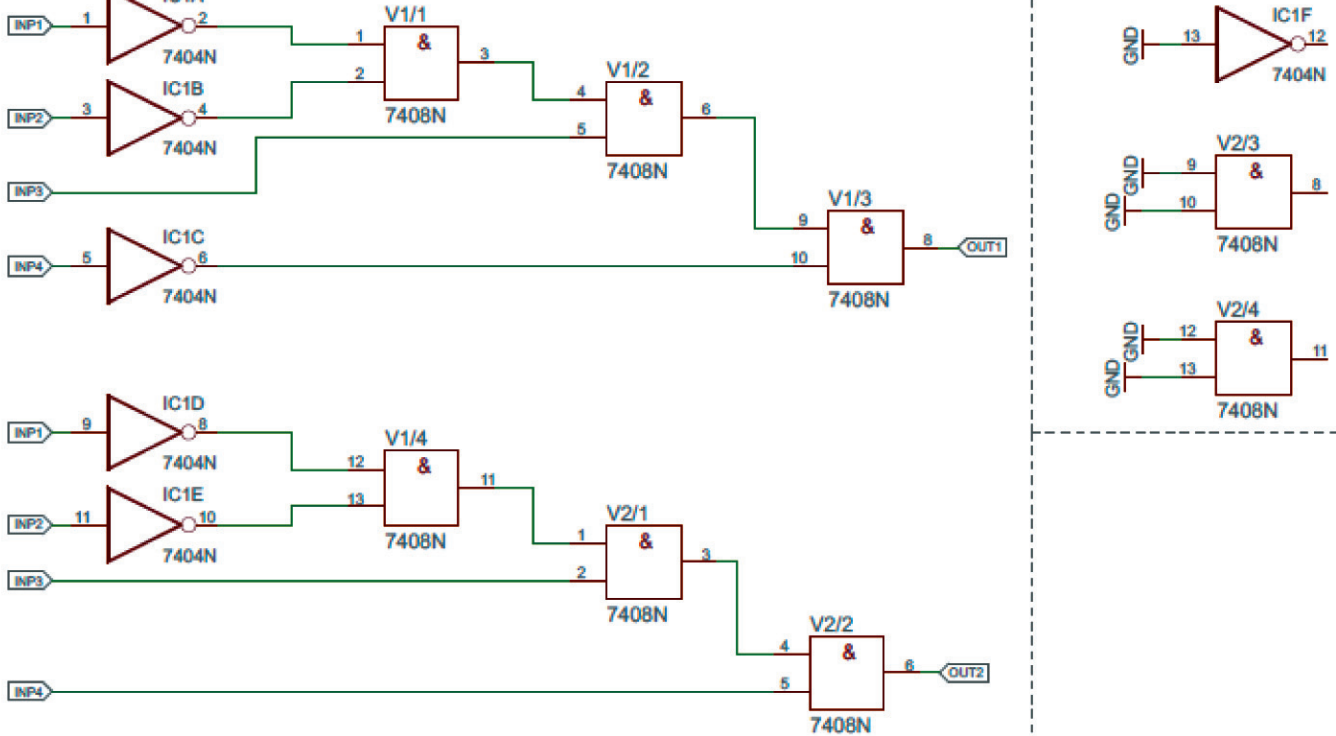

Fig. 5. Example of one logic gate board used to control the pluck of first relay; out1 and out2 are connected to a flip flop

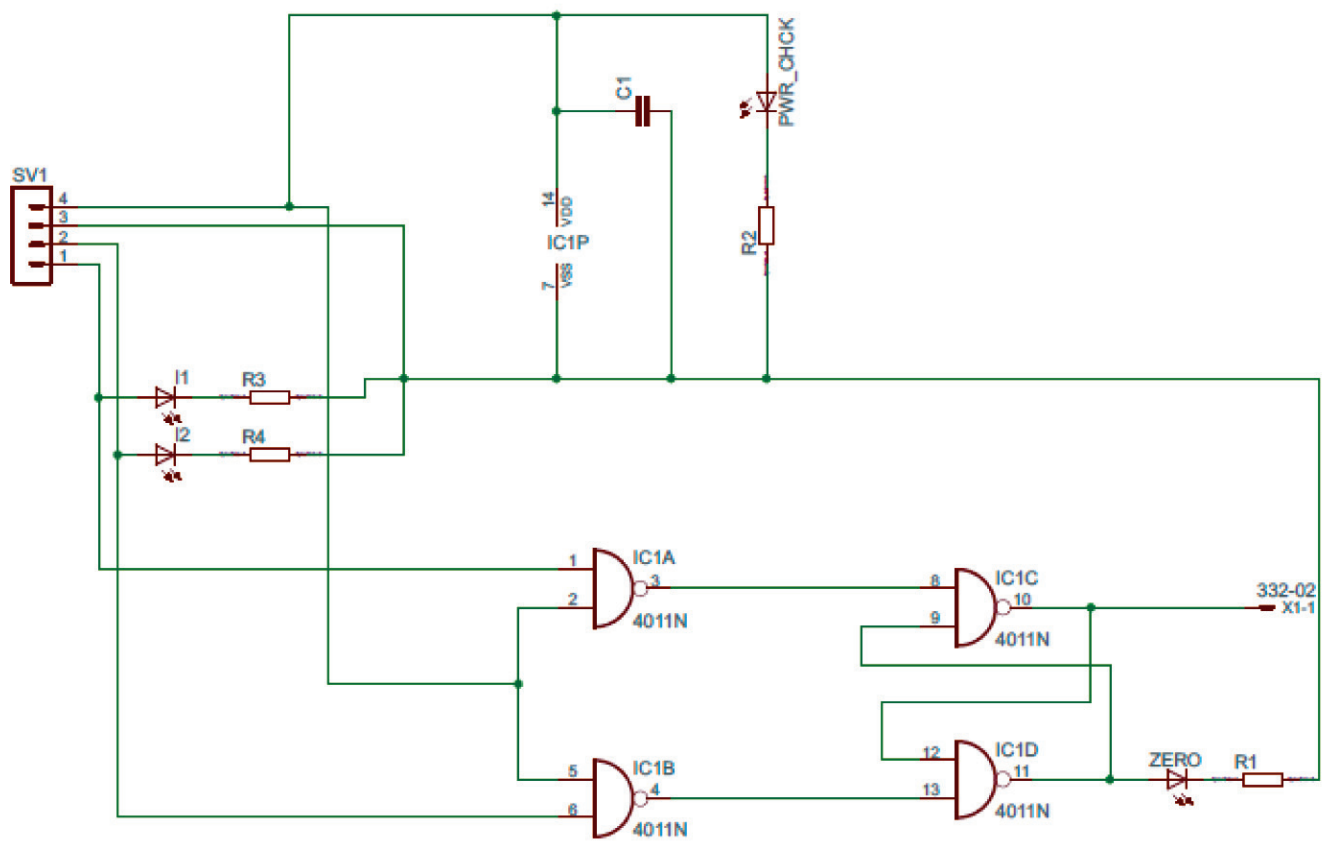

Fig. 6. Flip flop schematics; output X1-1 is connected with $\mathrm{H}$ bridge input 


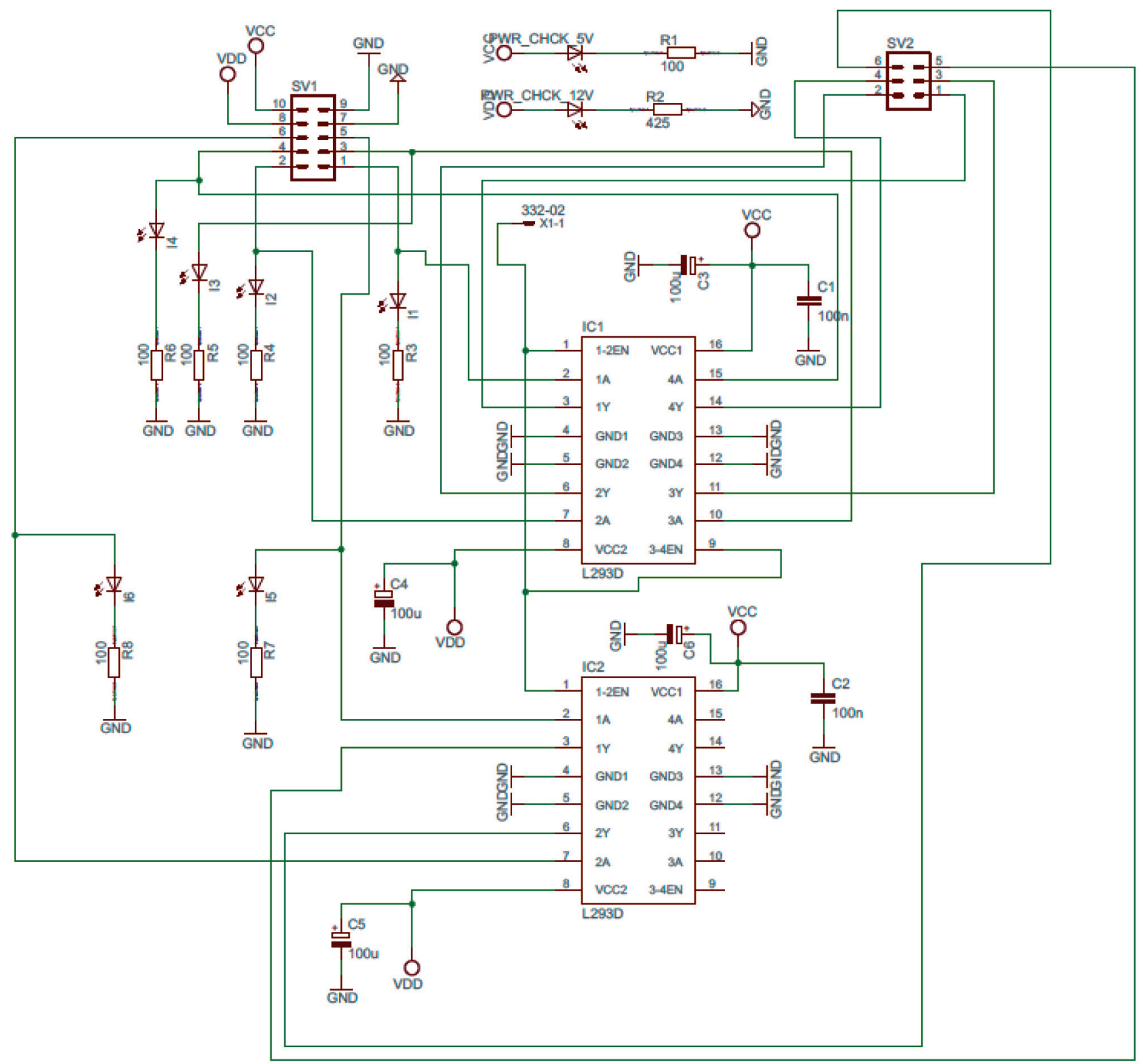

Fig. 7. H bridge schematics; outputs SV2 were connected to the relays

When the pluck is performed, an electrical impulse is applied to the relay and an electromagnetic field is produced. It pulls the movable metal part towards the coil core. A guitar pick is mounted on this movable plate, so it plucks the string and produces the sound. The coil is kept by the controller in this state until it is required to produce the sound again. When it comes to that, the power to the coil is cut, and the spring mounted on the automotive relay brings the part with the guitar pick back to the starting position, generating the pluck and inducing the sound on the string. The biggest advantage of such a solution is that the device can achieve a very high speed of plucking. The plucking module built for this robot was able to achieve a 10-ms reaction time between plucks. The world fastest guitar player was able to play 27 notes per second, so his repetition interval was about $37 \mathrm{~ms}$ between plucks.

The string-pushing module is used to press the string on the proper fret to change its length and produce the desirable pitch. The main parts of the left-hand simulation module are the servo mechanisms. They are mounted over the guitar neck in a special construction. Together with the pushing extenders, they make pressure devices. In this version of the robot, four pressure devices are used to change the effective string length and pitch of the sound. This is a sufficient amount for our experimentation. The positioning of the pressure device is variable and can easily be changed. Thanks to the high torque of 
the servos, the robot can react very quickly to play fast sequences of varying pitches.

The main element responsible for control is a Raspberry Pi microcomputer (Upton and Halfacree 2014). The Raspberry Pi alone is not enough to control the robot mechanism; the reason for this is that, from the 26 GPIO pins, only 8 can be used as an output (and the system requires at least 10 outputs). For the purpose of this design, logic-gate combinations were used. Logic gates are used to determine the address of the output where the signal should be directed. Also for the proper operation of the whole system, some additional electronics like $\mathrm{H}$ bridges and flip flops were used. The logic gates were mounted on the PCBs (Fig. 5).

Each PCB was responsible for driving a signal into one relay. The output from the logic system was driven to a flip flop (Fig. 6) that held or released the signal.

The robot's control system was powered by $5 \mathrm{~V}$ DC, but the plucking mechanisms required 12 V DC. Amplification of the voltage driven to the relays was required. Usually an $\mathrm{H}$ bridge is used to assist the control of the motors. In this case, its ability to provide a secondary voltage that could be higher than the one used to power the whole system helped solve the voltage amplification problem. The output from the flip flops was transferred to the $\mathrm{H}$ bridge (Fig. 7), and then the amplified voltage was driven to the proper relay, and a pluck was performed.

\section{RESEARCH}

\subsection{Research hypothesis}

For the purpose of the research presented in this paper, the following hypothesis has been stated:

- By using RMI, it is possible, to obtain repeatability of playing higher than that obtained from human-musician playing.

Repeatability in this case refers to the time intervals between the played notes in the sequences.

\subsection{Research methodology and sample analysis}

The research concentrated on the technical performance of playing. The human player was instructed to play clear sounds matching the provided tempo without adding any dynamics nor special plucking techniques. The reason for this was to obtain comparable and similar recordings of the played sequences.

The research was conducted with the help of a professional musician. Firstly, the guitar was tuned, then the human performer started to play the same note sequence several times. Then, the guitar was checked if it is still in tune, and the robot was mounted onto it. Then, when the robot was calibrated, it played the same note sequence the same number of times. Both performances were recorded, and sound samples were prepared for further analysis.

The research was conducted in the recording studio belonging to the Department of Mechanics and Vibroacoustics at AGH University. The microphone was positioned according to instrumental recording standards.

To obtain the answer on whther the RMI is at all helpful in the research, it was important to check if the robot could play repeatability better than a human. To determine the repeatability of the robot and human, it was necessary to compare the recordings samples. The method used for this purpose was to compare the RMS values of the signal samples. The recorded data was split into samples of the same note sequence. The sampling rate of the obtained signals was $44100 \mathrm{~Hz}$. In the RMS, a Hamming window of size 256 was used.

\section{RESULTS AND CONCLUSIONS}

In order to obtain the results, the samples were prepared, so they could be used in further analysis. The first step was to create spectrograms of human and robot playing and compare them to each other to see if there were any noticeable differences (Fortuna et al. 1993). Five sample examples were chosen for the purpose of this article. It can be clearly seen that the samples of the robot playing are very much alike, as opposed to the samples of the human performance. Figures 8 and 9 show the spectrograms. Each of the five spectrograms in the figure represents one note sequence played. In Figure 9, the authors marked one of the distortions that can be seen before the musician plucks the string. This distortion resulted from releasing the finger from a fret before the string is plucked. Due to the synchronization of plucking and pushing the string, this phenomenon does not occur in the robot's playing. 


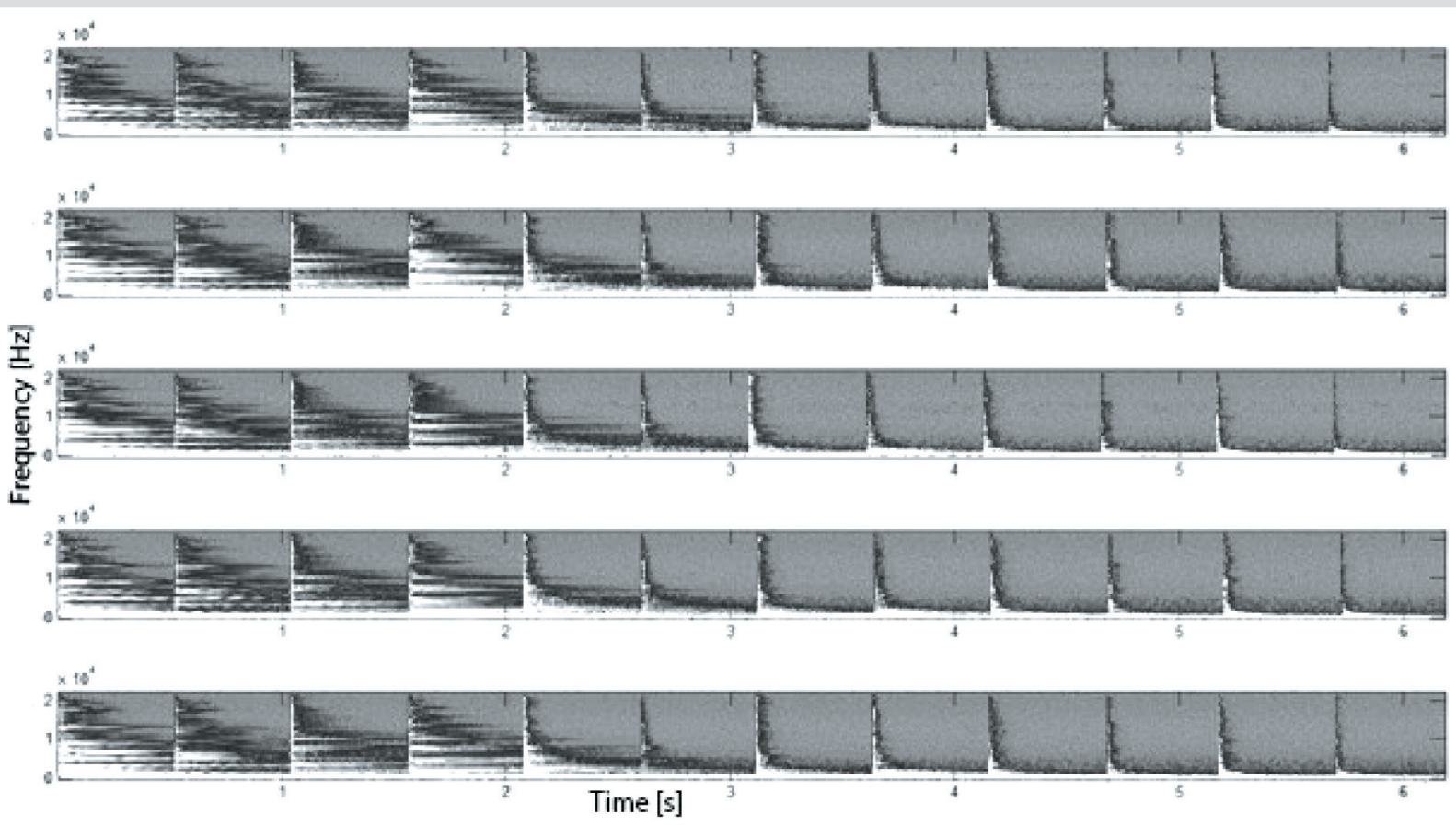

Fig. 8. Spectrogram of sounds played by robot
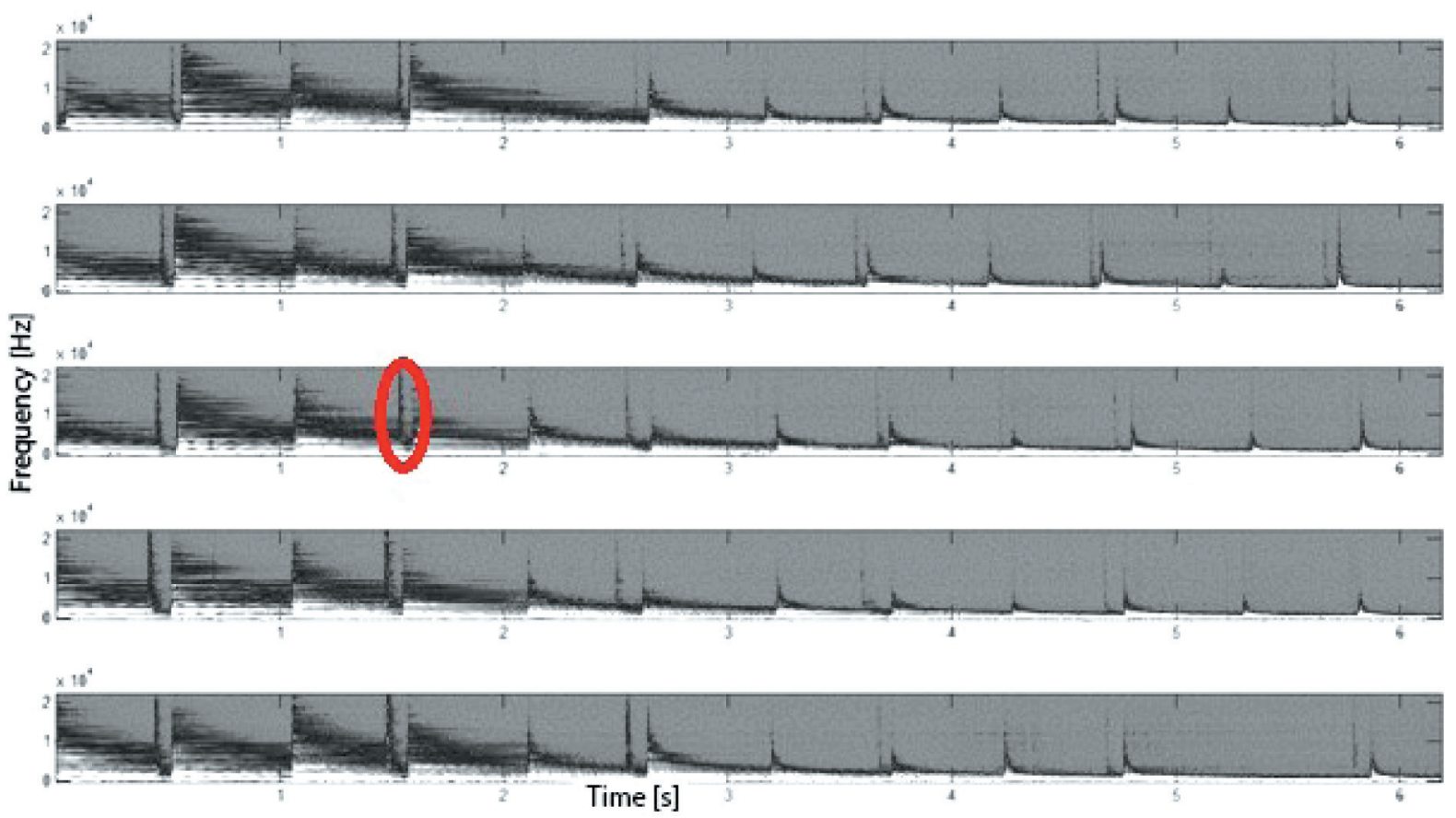

Fig. 9. Spectrogram of sounds played by guitarist.

Red ellipse marks one of the distortions that resulted from early string push release

Table 1 shows the result of the heterogeneity calculation. The results show that the robot has better repeatability than the human musician in the aspect of time intervals between played notes in the sequences. In order to estimate the repeatability, each sound sample was compared to each of the others (separately for the musician and robot), and the plucking heterogeneity based on Euclidean distance was calculated.
The perfect repeatability for this case would have the value of 0 :

$$
P H=\sqrt{\sum_{i=0}^{N-1}\left(x_{i}-y_{i}\right)^{2}}
$$

where:

$x_{i}$ - values of the amplitude spectrum of one sample, $y_{i}$ - values of the amplitude spectrum of another sample, $N$ - number of samples in spectrum. 
Table 1

Results of plucking heterogeneity calculation

\begin{tabular}{|c|c|c|c|c|c|}
\hline \multicolumn{6}{|c|}{ PH values from robot's playing } \\
\hline $\begin{array}{c}\text { Number of } \\
\text { sample }\end{array}$ & $\mathrm{S}_{1}$ & $\mathrm{~S}_{2}$ & $\mathrm{~S}_{3}$ & $\mathrm{~S}_{4}$ & $\mathrm{~S}_{5}$ \\
\hline $\mathrm{S}_{1}$ & 0 & 0.005 & 0.006 & 0.002 & 0.001 \\
\hline $\mathrm{S}_{2}$ & & 0 & 0.0007 & 0.003 & 0.005 \\
\hline $\mathrm{S}_{3}$ & & & 0 & 0.003 & 0.004 \\
\hline $\mathrm{S}_{4}$ & & & & 0 & 0.003 \\
\hline $\mathrm{S}_{5}$ & & & & & 0 \\
\hline \multicolumn{3}{|c|}{ Mean value of robot's $P H$} & \multicolumn{3}{|c|}{0.001} \\
\hline \multicolumn{6}{|c|}{ PH values from human's playing } \\
\hline $\begin{array}{l}\text { Number of } \\
\text { sample }\end{array}$ & $\mathrm{S}_{1}$ & $\mathrm{~S}_{2}$ & $\mathrm{~S}_{3}$ & $\mathrm{~S}_{4}$ & $\mathrm{~S}_{5}$ \\
\hline $\mathrm{S}_{1}$ & 0 & 0.006 & 0.005 & 0.002 & 0.004 \\
\hline $\mathrm{S}_{2}$ & & 0 & 0.001 & 0.008 & 0.006 \\
\hline $\mathrm{S}_{3}$ & & & 0 & 0.007 & 0.004 \\
\hline $\mathrm{S}_{4}$ & & & & 0 & 0.003 \\
\hline $\mathrm{S}_{5}$ & & & & & 0 \\
\hline \multicolumn{3}{|c|}{$\begin{array}{c}\text { Mean value of human's } \\
\text { PH }\end{array}$} & \multicolumn{3}{|c|}{0.004} \\
\hline
\end{tabular}

The obtained research results show that the RMI achieves steadier time intervals between the sound in the sequence than the ones in a human musician's playing. The robot obtained higher repeatability for technical playing at a set pace. Elimination of the human factor reduces the errors that occur during the performance of the sequence. This is positive for the purpose of research on the produced sound. The device presented in the paper can be used, for example, in research on the influence of the pluck position and angle on the sound produced. Of course, this is only done for scientific purposes, as mechanical musicians still will not be able to express music as a human performer for a long time. Or will they?

\section{References}

Delekta R.J., Pluta M., 2015, Implementacja regut wykonawczych w syntezie dźwięku instrumentów dętych zmodyfikowana metoda samplingowa. Proceedings of XVI International Symposium on Sound Engineering and Tonmeistering ISSET' 2015, Warszawa, 119-125.

Fortuna Z., Macukow B., Wąsowski J., 1993, Metody numeryczne. Wydawnictwa Naukowo-Techniczne, Warszawa.

Kapur A., 1983, A history of robotic musical instruments. International Computer Music Conference 2005, Barcelona, Spain.

Rasmussen J., 1983, Skills, rules, and knowledge; signals, signs, and symbols, and other distinctions in human performance models. IEEE Transactions on Systems Man, and Cybernetics, smc-13(3), 257-266.

Sali S., Kopac J., 2000, Measuring the quality of guitar tone. Proceedings of the 2000 IMAC-XVIII: A Conference \& Exposition on Structural Dynamics, Society for Experimental Mechanics, San Antonio, TX 2000.

Tokarczyk D., 2014, A guitar playing robot. MSc. dissertation, Akademia Górniczo-Hutnicza, Kraków.

Tokarczyk D., 2015, Stanowisko do badań wplywu elementów składowych gitary na jej barwę [in:] Opieliński K.J. (red.), Postępy akustyki. Polskie Towarzystwo Akustyczne. Oddział we Wrocławiu, Wrocław.

Upton E., Halfacree G., 2014, Raspberry Pi user guide. 3rd Edition. John Wiley \& Sons, Chichester. 